\title{
Msx2-Interacting Protein
}

National Cancer Institute

\section{Source}

National Cancer Institute. Msx2-Interacting Protein. NCI Thesaurus. Code C115312.

Msx2-interacting protein (3664 aa, $402 \mathrm{kDa}$ ) is encoded by the human SPEN gene. This protein plays a role in the negative regulation of gene transcription. 